Website: ijetms.in Issue:5, Volume No.4, September-2020 DOI: DOI: 10.46647/ijetms.2020.v04i05.017

\title{
STUDY ON UTILIZATION OF ZEOLITE AND STONE DUST IN CONCRETE
}

\author{
U Leela Prasanth ${ }^{1}$, H Karan Kumar ${ }^{2}$, Syed Afzal Basha ${ }^{3}$ \\ ${ }^{1} U G$ Student, Dept of Civil Engineering, G Pullaiah College of Engineering \& Technology, Kurnool \\ ${ }^{2} U G$ Student, Dept of Civil Engineering, G Pullaiah College of Engineering \& Technology, Kurnool \\ ${ }^{3}$ Associate Professor, Dept of Civil Engineering, G Pullaiah College of Engineering \& Technology, Kurnool \\ ${ }^{1}$ leelaprasanth27@gmail.com \\ ${ }^{2}$ karanking087@gmail. com \\ ${ }^{3}$ syedafzal 74 @gmail. com
}

\begin{abstract}
Concrete is a compound material composed of fine aggregates and coarse aggregate bonded together with fluid cement that hardens over time.The deficit of natural sand arises the need of alternative materials for replacement of natural sand. The squashed stone residue which is locally accessible modern strong waste material is ordinarily utilized as a fine aggregate in concrete. In the current examination, an exploratory program was carried out to consider the compressive and split tensile quality of concrete made utilizing stone residue as halfway substitution of fine aggregate at an increment of $10 \%$. Zeolite is a pozzolanic material and its pozzolanic action improves the compressivestrength of concrete. Natural zeolites are supplementary cementitious materials. By adding zeolite, the investigation on the experiments will be carried out to determine the compressive strength and split tensile strength of concrete made using zeolite as partial replacement of cement up to 20 percent at an interval of 5 percent just as the way Stone dust is being replaced to achieve the objective of the project, M30 grade of concrete is prepared. The cube and cylindrical samples shall be tested after a curing period of $7 \& 28$ days.
\end{abstract}

Key words-- Concrete, zeolite, stone dust, compressive strength, split tensile strength

\section{INTRODUCTION}

The concrete is a composite material which is overwhelmingly utilized everywhere throughout the world. It is a composite material which is comprised of cement, sand, aggregate and water. The life of the concrete is extremely high so it tends to be utilized as adaptable material.The strength characteristics of concrete depend upon the properties of constituent material and their combined action. In the concrete the cement is used as the binder material which has the binding tendency. Fine aggregate is one of the important constituent materials as far as strength characteristics of concrete are concerned. Because of increase in activities for different regions and utilities scaring of the naturally available resources is being constrained due to it's over abuse. This may cause threat to the environment. Hence conservation of the naturally available material is great challenge for the civil engineers.
The concrete industry is one of the two biggest makers of carbon dioxide $(\mathrm{CO} 2)$, making up to $8 \%$ of overall manmade discharges of this gas, on the off chance that we can somewhat supplant the cement with the material with alluring properties then we can spare common material and decrease outflow of $\mathrm{CO} 2$ in to the climate. Characteristic zeolite rocks are referred to have the option to go about as Supplementary Cementitious Materials (SCM) in Portland cement based concrete. By and large, SCMs are responding with portlandite and giving restricting hydration items similarly as Portland cement does. Along these lines a SCM can substitute certain amount of Portland cement in concrete and in this way decrease the related vitality utilization and $\mathrm{CO} 2$ emission.

Increment sought after and decline in common wellsprings of fine aggregate for the creation of concrete has brought about the need to recognize wellsprings of fine aggregate. Waterway sand which is most generally utilized as fine aggregate in the creation of concrete and mortar represents the issue of intense lack in numerous territories. The Stone residue created from stone squashing zones shows up as an issue for powerful removal.The disposal of this dust is serious environmental problem. Which is used here as partially replacement of fine aggregate. By incomplete substitution of characteristic stream sand then this won't just spare the expense of development and yet will take care of the issue of removal of this residue. Concrete made with this substitution can achieve the equivalent compressive quality practically identical tensile strength and modulus of rupture.

This project describes the feasibility of using the zeolite and Stone dust in concrete as partial replacement of cement and fine aggregate.

\section{LITERATURE REVIEW}




\title{
International Journal of Engineering Technology and Management Sciences[IJETMS]
}

\author{
Website: ijetms.in Issue:5, Volume No.4, September-2020 DOI: DOI: 10.46647/ijetms.2020.v04i05.017
}

Meysam. Najimi et.al: Examined the utilization of regular zeolite as a valuable cementitious material. To this point, some mechanical and strength properties of concrete made with $15 \%$ and $30 \%$ of normal zeolite are concentrated in correlation with concrete without characteristic zeolite substitution. Be that as it may, acceptable execution was not seen in corrosive condition. Out and out, from the reasonable perspective, the joining of $15 \%$ common zeolite was found as a fitting choice for improving quality and solidness properties of concrete[1].

B.Uzal et.al: Considered the Pozzolanic action of clinoptilolite, the most widely recognized normal zeolite mineral, was concentrated in contrast with silica rage, fly debris and a non-zeolitic regular pozzolan. The outcomes demonstrated that the clinoptilolite had a high limepozzolan reactivity that was practically identical to silica smolder and was higher than fly debris and a non-zeolitic regular pozzolan [2].

F. Canpolat et.al: Considered the impacts of zeolite, coal base debris and fly debris as Portland cement substitution materials on the properties of concrete are explored through three unique blends of tests. These materials are fill in for Portland cement in various extents, and physical properties, for example, setting time, volume development, compressive quality and water consistency of the mortar are resolved. The results showed increase in compressive strength at early ages, but resulted in a decrease in compressive strength when used in combination with fly ash. The results obtained were compared with Turkish Standards (TS), and it was found that they are above the minimum requirements [3].

Nagraj T.S et al (1996): He revealed that rock dust because of its higher surface zone expends greater cement in contrast with sand which builds usefulness. He considered the impact of rock residue and rock as aggregate in cement and concrete and found that squashed stone residue could be utilized to supplant the regular sand in concrete. The blend configuration presented by Nagaraj T.S announced that there are three prospects of guaranteeing the usefulness specifically mix of rock residue and sand, utilization of super plasticizers and change water content [4].

A.K. Sahu et al (2004): He explored the fundamental properties of regular concrete and concrete made utilizing quarry dust have analyzed. They have contemplated M20 and M30 blends. Identical blends are acquired by supplanting stone residue mostly/completely. Test results indicate effective usage of stone dust with same compressive strength, comparable tensile strength and modulus of rupture. Workability is increased by the addition of Super plasticizer [5].
Syam Prakash V., Krishnan D. and Jeenu G:They researched the impact of stone residue on M60 evaluation of high strength concrete. They contemplated compressive quality, split elasticity, flexural quality, corrosive obstruction property, water assimilation trademark, and porosity through their trials. Various examples of conventional concrete and stone residue concrete were arranged and tried. It was reasoned that reinforce properties like compressive quality and rigidity expanded when stone residue was supplanted by over $60 \%$ [6].

\section{EXPERIMENTATION}

\section{A. Materials Used}

Cement:Cement, as a binding material, is a very important building material. Ordinary Portland cement (OPC) is by far the most important type of cement. Ordinary Portland cement 53- grade of Ultra tech brand confirming to B.I.S. standard is used in the present investigation. The cement is tested for its various properties as per IS: 4031-1988 and found to be confirming to the requirements as per IS: 8122 1989.

Fine aggregate:The sand used in this investigation is ordinary river sand. The sand is free from clayey matter, silt and organic impurities etc. The sand passing through $4.75 \mathrm{~mm}$ size sieve is used in the preparation of specimens. The sand adjusts to grading Zone-II according to IS: 3831970. The properties of sand, for example, fineness modulus, water ingestion and explicit gravity were resolved according to IS: 2386-1963.

Coarse aggregate: The coarse content utilized in the examination is $20 \mathrm{~mm}$ down size locally accessible squashed stone got from quarries. Particulars for coarse total are remembered for IS: 383-1970. The physical properties have been determined as per IS: 2386-1963. The coarse aggregate is free from clayey matter, silt and organic impurities etc. The specific gravity of coarse aggregate is 2.75 .

Water:The water used in the mix design was potable water and it is free from suspended solids and organic materials, which might affect the properties of the fresh and hardened concrete. The water should be colorless and odorless. The presence of chlorides and sulphates are injurious to reinforcing bars as they may be corroded.

Stone dust:Stone dust, is a by-product releases from the cutting and crushing process of stone which is a concentrated material to use as fine aggregates. There are many quarries are present around Kurnool district of Andhra Pradesh state. The total waste produced by these industries is more than 50 tons per day. We are using Stone dust as a fine aggregate replacement in different 
Website: ijetms.in Issue:5, Volume No.4, September-2020 DOI: DOI: 10.46647/ijetms.2020.v04i05.017

percentages. The waste material i.e., Stone dust is obtainedfrom Betamcharla of Kurnool Dist. in A.P. and its specific gravity is 2.5 .

Zeolite: Zeolites are micro porous alumino silicate minerals. These are added to the Portland cement as a pozzolan and water supply to decrease chloride penetrability and to improve functionality. Zeolites are crystalline solids structures made of silicon, aluminum and oxygen that structure a system with cavities and channels inside where cations, water and additionally little particles may live.

\section{B. Method of Casting}

Cement, fine aggregate and coarse aggregate were taken in mix proportion 1:1.8:2.4 which correspond to M30 grade of concrete. Fine aggregate is replaced with Quarry dust as $10 \%, 20 \%, 30 \%, 40 \% \& 50 \%$. All the fixings were dry blended homogeneously. To this dry blend, required amount of water was included $(\mathrm{W} / \mathrm{C}=0.44)$ and the whole blend was again homogeneously blended. This wet concrete was filled the molds which was compacted through hand compaction in three layers and afterward kept into the vibrator for compaction. After the compaction, the examples were given smooth completions. Following 24 hours, the examples were demoulded and moved to relieving tanks where they were permitted to cure for individual 7,28 days. We are using M30 blend for this trial.

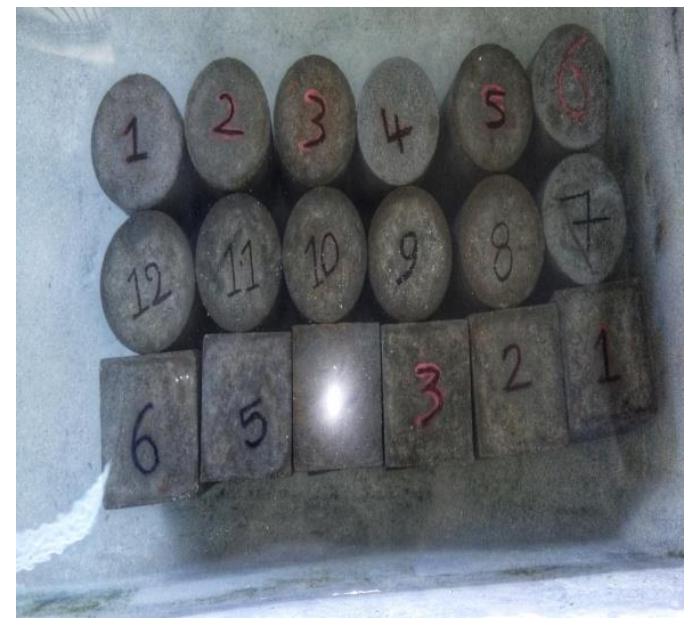

Fig-1 Samples in curing pond

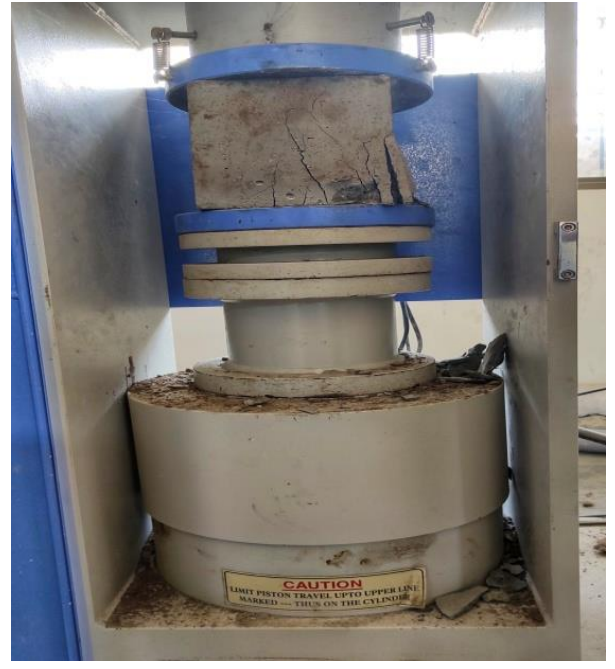

Fig-2 Testing of cube specimen

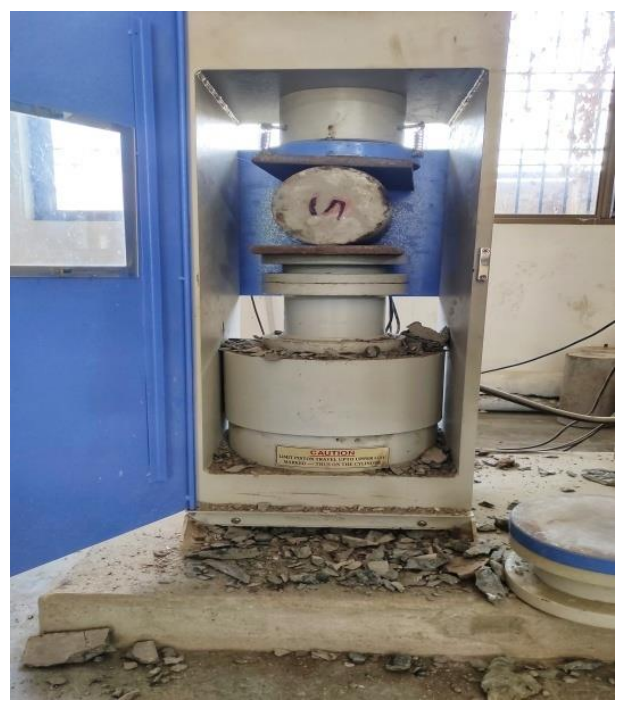

Fig-3 Testing of cylindrical specimen 
Website: ijetms.in Issue:5, Volume No.4, September-2020 DOI: DOI: 10.46647/ijetms.2020.v04i05.017

IV. RESULTS

TABLE I

TEST RESULTS BY REPLACING SAND BY STONE DUST

\begin{tabular}{|c|c|c|c|c|c|}
\hline \multirow{2}{*}{ Mix } & Nomenclature & \multicolumn{2}{c|}{$\begin{array}{c}\text { Compressive } \\
\text { Strength } \\
\text { (MPa) }\end{array}$} & $\begin{array}{c}\text { Split Tensile } \\
\text { strength } \\
\text { (MPa) }\end{array}$ \\
\cline { 3 - 7 } & & $\begin{array}{c}\mathbf{7} \\
\text { days }\end{array}$ & $\begin{array}{c}\mathbf{2 8} \\
\text { days }\end{array}$ & $\begin{array}{c}\mathbf{7} \\
\text { days }\end{array}$ & $\begin{array}{c}\mathbf{2 8} \\
\text { days }\end{array}$ \\
\hline R1 & $0 \%$ SD + 100 \% Sand & 23.77 & 37.52 & 2.64 & 4.04 \\
\hline R2 & $10 \%$ SD + 90 \% Sand & 20.79 & 36.88 & 1.82 & 3.55 \\
\hline R3 & $20 \%$ SD + 80 \% Sand & 21.58 & 38.79 & 2.01 & 3.82 \\
\hline R4 & $30 \%$ SD + 70 \% Sand & 22.52 & 39.54 & 2.33 & 4.05 \\
\hline R5 & $40 \%$ SD + 60 \% Sand & 23.9 & 42.74 & 2.86 & 4.33 \\
\hline R6 & $50 \%$ SD + 50 \% Sand & 22.17 & 40.57 & 2.56 & 3.93 \\
\hline
\end{tabular}

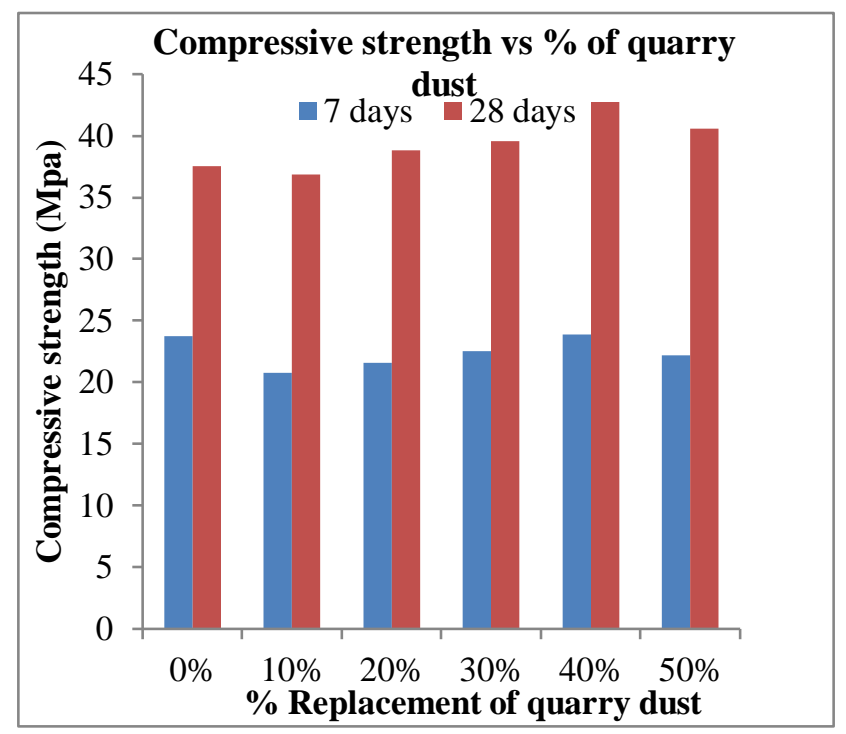

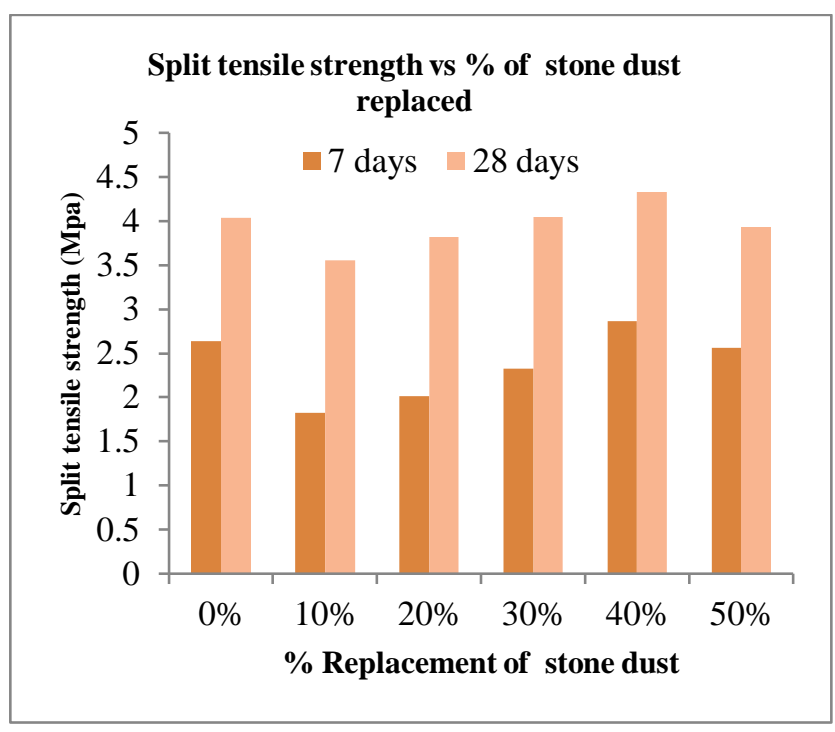

TABLE II

TEST RESULTS BY REPLACING CEMENT BY ZEOLITE

\begin{tabular}{|c|c|c|c|c|c|}
\hline \multirow{2}{*}{ Mix } & Nomenclature & \multicolumn{2}{|c|}{$\begin{array}{c}\text { Compressive } \\
\text { strength (MPa) }\end{array}$} & \multicolumn{2}{c|}{$\begin{array}{c}\text { Split Tensile } \\
\text { strength } \\
\text { (MPa) }\end{array}$} \\
\cline { 3 - 6 } & & $\begin{array}{c}\mathbf{7} \\
\text { days }\end{array}$ & $\begin{array}{c}\mathbf{2 8} \\
\text { days }\end{array}$ & $\begin{array}{c}\mathbf{7} \\
\text { days }\end{array}$ & $\begin{array}{c}\mathbf{2 8} \\
\text { days }\end{array}$ \\
\hline R7 & $\begin{array}{c}40 \% \text { S.D + 60\% } \\
\text { sand + 0 \% zeolite } \\
+100 \% \text { Cement }\end{array}$ & 35.65 & 42.86 & 2.87 & 4.34 \\
\hline R8 & $\begin{array}{c}40 \% \text { S.D + 60\% } \\
\text { sand + 5 \% zeolite } \\
+95 \% \text { Cement }\end{array}$ & 20.77 & 41.69 & 2.57 & 4.23 \\
\hline R9 & $\begin{array}{c}40 \% \text { S.D + 60\% } \\
\text { sand + 10\% zeolite } \\
+90 \% \text { Cement }\end{array}$ & 22.95 & 43.74 & 2.84 & 4.44 \\
\hline R10 & $\begin{array}{c}40 \% \text { S.D + 60 \% } \\
\text { sand + 15\% zeolite } \\
+85 \% \text { Cement }\end{array}$ & 25.65 & 46.55 & 3.04 & 4.75 \\
\hline R11 & $\begin{array}{c}40 \% \text { S.D + 60\% } \\
\text { sand + 20\% zeolite } \\
+80 \% \text { Cement }\end{array}$ & 23.94 & 44.53 & 2.78 & 4.55 \\
\hline
\end{tabular}


Website: ijetms.in Issue:5, Volume No.4, September-2020 DOI: DOI: 10.46647/ijetms.2020.v04i05.017
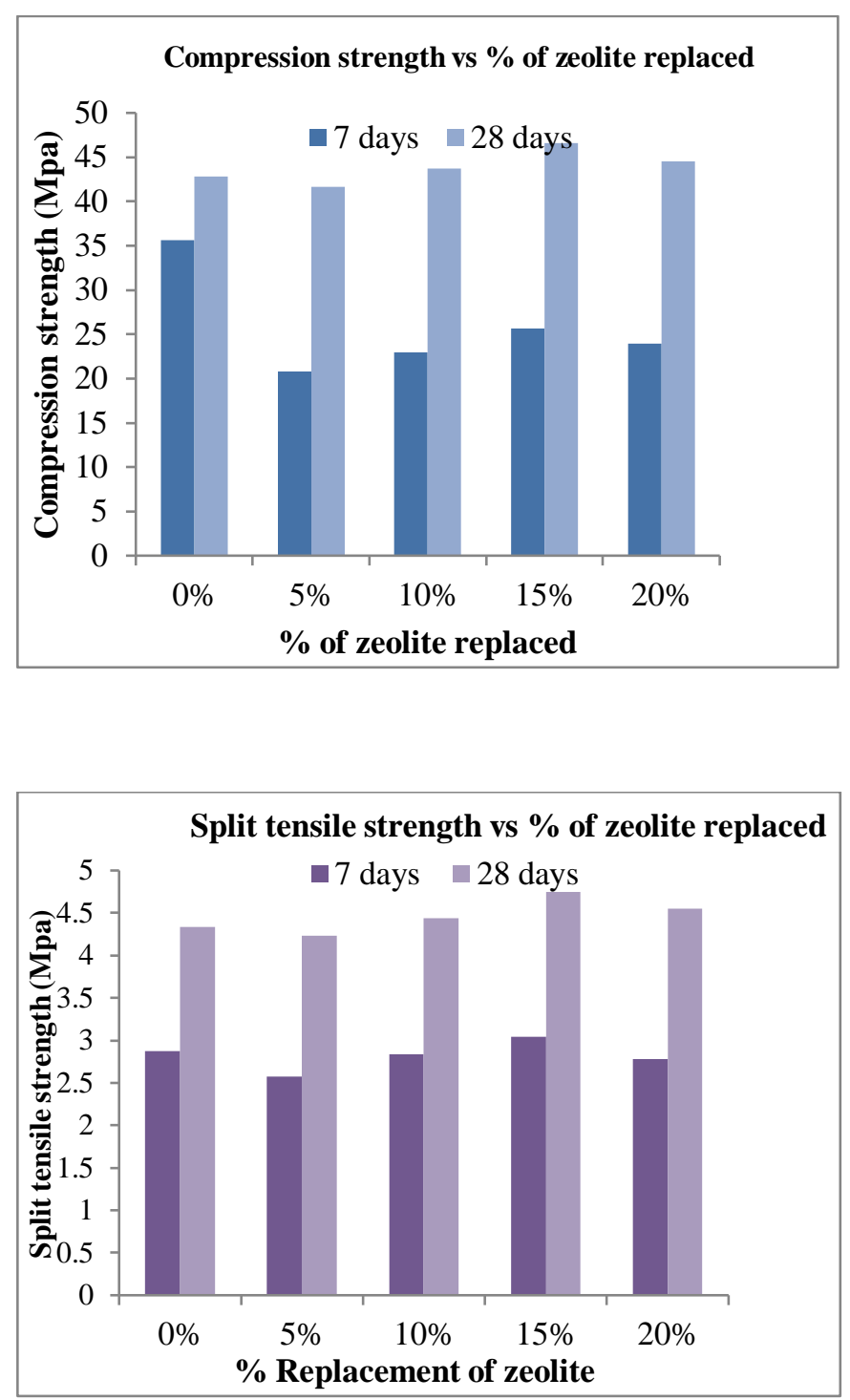

\section{CONCLUSIONS}

- $\quad$ Starting from $0 \%$ to $50 \%$ substitution of fine aggregate with stone residues, up to $40 \%$ replacement level, there is an increase in both compression and tensile strength values.

- Beyond $40 \%$ replacement of fine aggregate with Stone dust, there is a decrease in both compressive strength and tensile strength values.
- By adopting the combination of $60 \%$ of sand and $40 \%$ of Stone dust, cement is replaced with zeolite of $5 \%, 10 \%, 15 \%$, and $20 \%$.

- Starting from $0 \%$ to $60 \%$ replacement of cement with zeolite, up to $15 \%$ of replacement level of cement with zeolite, there is an increase in both compressive strength and tensile strength and at $15 \%$ to $20 \%$ both compressive strength and tensile strength values decreased.

- From the experimental investigation it is concluded that zeolite can be replaced up to $15 \%$ in place of cement and optimum percentage of zeolite is $15 \%$.

- Using $60 \%$ of sand, $40 \%$ of Stone dust, $85 \%$ of cement and $15 \%$ of zeolite in concrete mix gave higher compressive strength and tensile strength values than nominal concrete mix.

\section{References}

[1] MeysamNajimi: "An experimental study on durability properties of concrete containing zeolite as a highly reactive natural pozzolan" Construction and Building Materials 35 (2012) 1023-1033.

[2] B. Uzal: "Pozzolanic activity of clinoptilolite: A comparative study with silica fume, fly ash and a non-zeolitic natural pozzolan" Cement and Concrete Research 40 (2010) 398-404.

[3] F. Canpolat: "Use of zeolite, coal bottom ash and fly ash as replacement materials in cement production" Cement and Concrete Research 34 (2004) 731-735

[4] Nagaraj. T.S (1996): "Efficient utilization of rocks dust and pebbles as aggregate in Portland cement concrete", The Indian concrete journal, Vol. 70, No.1, PP14.

[5] A.K. Shau and A.K. Sachan (2003): "Crushed stone waste as fine aggregate for concrete" the Indian concrete journal, pp 845848.

[6] Prakash V.S, Krishnan D and Jeenu G. (2007): Influence of fine stone dust on high strength concrete. 32nd Conf. on our world in concrete and structures, 28-29 August 2007, Singapore Article Online Id: 100032054, 2007.

[7] E.Vejmelkoval, T. Kulovaná (2012) "Natural zeolite as environmentally friendly supplementary cementitious material in concrete" 275, 2012.

[8] Ali Akbar Ramezanianpour, Ali Kazemian (2013) "Use of Natural Zeolite to Produce Self-Consolidating Concrete with Low Portland cement Content and High Durability" 275, 2013. 